\title{
The Use of French Grammar in Writing North Sumatera Culinary Recipes
}

\author{
Jubliana Sitompul ${ }^{1}$, Marice Pangaribuan ${ }^{2}$, Junita Friska ${ }^{3}$ \\ \{jubliana_professeur@yahoo.co.id ${ }^{1}$ \} \\ Department of Universitas Negeri Medan, Indonesia ${ }^{1,2,3}$
}

\begin{abstract}
Writing is an activity expressing the way of thinking, feeling in text. Written language requires the writer to have certain skills, especially French learners. Writing culinary recipes in French also requires language skills in the use of positive articles, the formation of imperative speech and lexical mastery of culinary expressions. The text of culinary recipes in French is used as a learning medium that helps learners to increase their language skills. This paper was created to describe the use of positive articles, the formation of imperative speech and mastery of culinary expressions in French. The thing that prompted the writer to make a study about writing this culinary recipe because there were still errors in the students writing about some of the things mentioned earlier. Culinary recipes are chosen because this topic is interesting and familiar in the daily life of learners as well as motivating curiosity about local culture.
\end{abstract}

Keywords: writing recipe, partitive articles, imperative sentence

\section{Introduction}

The use of grammar in French is very important. Learning French by knowing grammar will increase the level of knowledge of the written and the oral, and will be able to interpret French correctly even if its use is not for the daily activities but if we control correctly the principles grammatical then the use of French would be better. The advantages of using grammar are to develop the art of translation, to help acquire vocabulary, to improve the knowledge of real sentences and to develop a conceptual reflection on the structure of the French language.

A correct grammar can be seen when writing a text. Writing is the ability to express ideas, opinions and feelings to others in text. According to Akhadiah (1998: 16), writing is the activity of delivering messages (ideas, feelings and information) in writing to others. The activity of writing it is not as easy as imagined. In writing, one must pay attention to the rules of grammar, unlike to speak where we can repeat the same word several times.

Writing courses are taught in 3rd semester. After attending writing class in one semester, some skills are expected to be mastered by students such as the ability to use the right articles and imperative sentences. To stimulate student's creativity in the use of articles and imperative sentences, new learning media need to be sought so that writing activities are not boring, one of them is by writing recipes. Writing recipes requires students to be adept at using articles, especially positive articles. Writing a recipe usually aims to instruct the reader to do as written so that it is very appropriate to be used in the learning of imperative sentences. 
Culinary recipes are also chosen, because food is something that is close to the daily life of students so that it is easier for students to learn grammar.

\section{Study Literature}

\subsection{The Function of Food}

This article aims to show that language learning through culinary recipes is very rich in knowledge. Understanding food is very broad. Eating is important to make a living (Papadopoulou :2016). Cooking and processing food is an activity that aims to answer vital needs and to make an important element of a new lifestyle. Eating is a social act. Élisabeth de la Fontaine. (2011) said eating as a social act because eating is a collective experience through acceptance from others. In eating activities, the situation is a moment to know others. The existence of a person at a meal shows a social role. For example, there is no party without food. Food becomes a communication tool for sharing experiences with others. However, religion also forbids followers to protect themselves from certain foods of Olivier. (2003: 244) in some beliefs are prohibited from eating certain foods. In this case, the adherent must show proof of loyalty in fulfilling the demands of religious regulations. In addition, eating allows for physical changes that result in disease and obesity.

\subsection{Writing and Culinary Recipes}

Writing recipes in French is found in old methods or new methods of learning French Writing recipes in French learning is usually called cooking. In general, writing recipes can be found in any French teaching method such as: French Methods Alter Ego 1 (2006: 35, 114117), Version 1 (2001: 14-15, 94-105), Editorial 1 (2016: 33, 47) and Tendance 2 (2016: 2426). According to Stenkløf (2014: 67), the recipe is a text that contains a description of the cooking ingredients and how to do something about it. So, a cooking recipe is a process that indicates all the ingredients and operations needed to perform food preparation in the kitchen using utensils. In particular, it specifies, for a given number of persons, the quantities of each ingredient, the preparation and cooking times and, where appropriate, the method of cooking. The different operations to be performed are often described using specialized terms specific to cooking techniques. Recipes are often a variation of the staple diet of a particular crop.

Writing and cooking recipe have a very close relationship. The cooking recipe is a kind of injunctive text. This text is a text that proposes an action or gives instructions to a recipient. According to Amira (2017: 15), writing the injunctive text must be considered several things, namely the use of verbs, articles, adjectives, cooking terms, vocabularies and even prepositions. Based on the above explanation, it can be concluded that writing the recipe must be fit to the rules of grammar so that the recipe is grammatically structured.

\subsection{Writing and Grammar}

Writing is one of the most complex aspects of language skills. It's said complicated, because writing is a source of other language skills and still needs to be supported by linguistic knowledge in a satisfactory way. According to Cuq and Gruca(2002: 178) writing is a complex process and acquiring written production skills is not an easy task, because writing 
a text is not about producing a series of suitable linguistic structures but about making a series problem-solving procedure that is sometimes difficult to distinguish and structure. This is in agreement with Nunan's (1989: 57) opinion that writing it is a complex cognitive activity because at the same time the author has to establish a number of varieties. Variety in sentence level includes content layout, order, sentence structure, vocabulary, punctuation and spelling, while variety outside phrase consist and combine sentences in one paragraph. According to Tarigan (2008: 3), writing is a language skill used to communicate indirectly and not face-toface with others. While Crimmon's own writing ability (1984: 3) is the ability to pour thoughts into written language through sentences that are linked together, complete and clear so that thought can be communicated to the reader with success.

Based on some of the above opinions, it can be concluded that writing is a human activity that is done in a directed and conscious direction towards ideas, thoughts, feelings or experience in the form of organized writing systematically using logical sentences, so that others can understand the purpose of the authors.

In writing activities, the learner must also learn grammar to better understand the meaning of the article. According to Tanriverdieva (2002: 44), the grammar of language is the set of rules that govern language as a system of social nature subject to collective agreements. It can be concluded that the activity of writing is inseparable from the use of grammar. According to Nugraheni \& Suyadi (2011: 27) argues that good writing is determined by the systematic writing used. A writing will be meaningful and interesting when using good sentence arrangements. Words should be arranged in grammatical sentences and cohesive passages. In addition, the text must be written using proper spelling and punctuation to make the meaning unambiguous. Thus, knowledge of grammar becomes an important preparation for students to write.

\subsection{Load of Grammar in Culinary Recipes}

\subsubsection{Noun and Article}

Nomina or often called a noun is a type of word that can usually serve as the subject or object of the clause. According to Bescherelle (2006: 188), the noun is a word that designates a person, an animal, or a thing. The noun is the core of the nominal group (sometimes called the leader of the group). Simone (1998: 16), says that the noun is a word that serves to designate, to "name", animate beings and things. In French, each noun is preceded by a determinant that indicates the gender and the number. The nouns are sorted by gender (male and female) and number (singular-plural). According to Loiseau (1993: 12), nouns generally preceded by a determinant that shows the type and number of names.

Example:

- Male noun: un verre, un four, un bol, un kilo, etc.

- Feminine noun: une casserole, une cuillère, une cuisinière, une tasse, etc.

In French, each noun must have an article. The article is a grammatical unit accompanying a French noun which serves to designate and limit the names that follow. The article is a linked morpheme that can not be left alone without a noun. This article has several functions. In general there are 3 types of article in French, these are: 1) Articles that work as unknown and unclear nominal markers are called indefinite articles 2) Articles that function as clear nominal markers are called definite articles and 3) the article used to declare the partial name (usually in the form of a kitchen or beverage) is called a partitive article. The use of articles varies in form according to gender (masculine-feminine) and number (singular-plural) of noun. 


\section{a. Indefinite Article}

The indefinite article expresses the fact that the noun with which it is associated denominates a thing or a living being unknown to the participants in the communication, in the sense that it has not been discussed during this one. It also indicates that what is named is not individualized in relation to the class of which it is a part, and the article only directs attention to the thing or being named without the exactly determine it.

The indefinite article, that is French nominal articles that function as a marker the noun are uncertain and not yet clear (Delatour, 2002: 37-39). According to Monnier (1998: 26-27), the indefinite article indicates that the being or the object designated by the noun remains indeterminate. It agrees in kind and in number with the name designates.

Singular (feminine): une,

Example: Une orange, une poire.

Singular (male): un,

Example: Un avocat, un chocolat

Plural (Feminine / Male): if the article un and une is formed in the plural, it becomes des and the noun is added with $\mathrm{s}$.

Example:

- Une orange becomes des oranges

- Un avocatbecomes des avocats

\section{b. Definite Article}

The definite article indicates that the noun with which it is associated is known to the participants in the communication situation, that it is individualized to a high degree, that it is exactly defined, that it names a certain thing or a certain being.

Singular (Feminine): la,

Example: la crêpe

L' (before vowel),

Example: L'escargot

Singular (Male) : le,

Example: le gâteau

Plural (Feminine / Male): if the article le andla is formed in the plural, it becomes les and the noun is added with $\mathrm{s}$ or $\mathrm{x}$.

Example:

- la crêpe becomes les crêpes

- $\quad$ le gâteau becomes les gâteaux

\section{c. Partitif Article}

The partitive article / species of the indefinite article is used in front of a concrete or abstract name to indicate an indeterminate quantity, a part of a whole that cannot be counted and for this reason it is used with non- accountants.

Example: avoir du courage, boire de l'alcool, boire de la bière.

According to some grammars, des is not only an indefinite article, but also partitive, when it is used with non-numeric names without singular : prendre des legumes. 
The partitive article, which is an article accompanying a French noun that serves as a partial name marker (usually cooking or drinking). According to Grevisse (2008: 745), a partitive article is an article listed in front of a name whose quantity can not be counted. The form of this article is a composite of the preposition of + defined article (le,la,les,l'). According to Monnier (1998: 32), the partitive article indicates an indeterminate quantity that is part of a whole. It is used before names of things that are not counted, which form a mass.

- $\quad$ Singular Feminine : de la,

Example : Je mange de la glace, de laviande, de lasalade

- De l' (before vowel),

Example: Je bois de l'eauminérale.

- Singular Male: du,

Example:Jebesoin du beurre et du sucre

After a negative verb, the partitive article becomes de/d' of when it determines a direct object and after the verb êtrein negative sentence, the partitive article does not change. A plural noun if followed by an adjective then the article of des is changed by de.

Example:

J'aimangéde latarte

If the sentence above is formed negative, article du of the is changed by : Je n'ai pas mangéde tarte

- C'est du thon

If the sentence aboveisformednegative, article du is not changedbecauseit uses the verb être: ce n'est pas du thon.

- Ils achètent de vieux livres.

The nounlivres uses the article de becauseit uses the adjective before the name.

So, for the indefinite article uses un (singular male), une (singularfeminine) and des (plural male / feminine). The definite article uses le (singular male), la (singularfeminine), l' (vowel and h) and les (plural male / feminine). The partitive article uses du (singular male), de la (femininesingular), de l' (beforevowel and h) and des (plural male / feminine).

\subsubsection{Imperative Sentence}

The imperative sentence expresses an order, suggestion, request or order / expectation. The imperative sentence of French can be in the form of inversion (reversal of subject and verb arrangement), conjugated in présent form ending in a period (.) Or an exclamation point (!). This sentence is used by someone to tell or command to do something as we wish. This sentence requires that the opponent speak to respond in the form of actions or actions requested by the speaker.

\subsubsection{Imperative Function}

Kridalaksana (2008: 91) explains that imperative incorporation is a form of sentence or verb to express an order or necessity or a prohibition to carry out an act. It's different from the definition by Dubois (1973: 251) which states that: 
(1) Imperative is a mode expressing an order gives one or more interlocator (in affirmative sentences) or defense (in negative sentences).

Example :

Mangezregulièrement.

Ne mangez pas beaucoup de viande.

(2) Generative grammary, the imperative is a type of sentence (or modality of sentence), like the interrogative) and the assertion (declarative sentence); it is a constituent of the basic sentence which, compatible only with the second person (o including a second person, committee you), triggers an imperative transformation; this one, including others, erases the pronouns subject of the phrase

Example;

Vous + venez + demain, becomes Venezdemain.

Mania (2004) declares restorative as a mode of action. It is not used to narrate, to describe, but to order, persuade, advise, etc. The implies a dialogue (real or fictional) in which the speaker tries to act on someone or something. The purpose of the imperative is motivated by various emotional movements.

To give instructions in a recipe or a job mode, one uses it is attractive. Aggressive estionus used to express:

- A commande :Mettez le beurredansune casserole.

- A deman : Passe le sel, s'ilteplaît.

- A wish : Mange ce plat chaud.

- An advice :mangezce plat sans sucre.

- A prohibition : ne mélangez pas avec unecuillère en métalmais en plastique.

- An instruction: Ajoutez le sucre.

\subsubsection{Formation of the Imperative}

The imperative has only 3 people (you, us and you). It is based on the present indicative. The verb is conjugated without the subject pronouns.

Table 1. formation of the imperative.

\begin{tabular}{|c|c|c|}
\hline INFINITIF & PRÉSENT & IMPÉRATIF \\
\hline Manger & $\begin{array}{c}\text { Tumanges } \\
\text { Nous mangeons } \\
\text { Vousmangez }\end{array}$ & $\begin{array}{c}\text { Manges-le chaud } \\
\text { Mangeons-le chaud } \\
\text { Mangez-le chaud }\end{array}$ \\
\hline
\end{tabular}

\section{Conclusion}

Writing a text needs a consistent sentence and the correct grammar. So, there is a very narrow in writing texts with the use of grammar. The text is the cooking recipe. This text uses Touarees the adjectives, tutoring lessons, the pronouns, the imprerative modes, the articles like're indefinite article, the definite article and the article particle. To achieve for cooking recipe exists certain expressions of lyilization of the phrase mode implication which is a more method of commissions an order, a request, a wish, a council, a prohibition an instruction 
Tables. All included tables must be referred to in the main text and the table title and caption are to be positioned above the table.The captions need to be written in Times New Roman, 9 pt.

\section{References}

[1] MAmira, Zinat.: Le texteinjonctifdans le manuelscolaire de la 5ème annéeprimaire. (2017)

[2] Akhadiah, Sabarti, dkk.: Pembinaan Kemampuan Menulis Bahasa. pp. 1-11 (2002)

[3] Assouly, Olivier.: Les Nourritures Divines. Les InterditsAlimentaire (2003)

[4] Crimmon, Mc.: Writing with a Purpose (1984)

[5] Cuq., Pierre, J., Gruca, I.: Cours de Didactique du Français Langue EtrangèreetSeconde (2002)

[6] Fontaine, E.: Manger, UnActe Global (2011)

[7] Grevisse, Amurice.: Le Bon Usage (2008)

[8] Loiseau, Yves.: Point par Point (1997)

[9] Monnier, Clay, S.: La GrammairePratique (1998)

[10] Nugraheni, Sri A, Suyadi.: Empat Pilar Pembelajaran Bahasa Indonesia (2011)

[11] Nunan, David.: Language Teaching Metodology A Texbook for Teachers (1989)

[12] Papadopoulou, Maria.: L'évolution De La Typologie De « La Recette » Au Cours D'un Siècle En Grèce (2016)

[13] Stenkløf,. Foucher, N.: "Épicerl'interprétation des textes: le genre est-ilunerecette et la recetteest-elle un genre?”. Vol. 9, pp. 63-77. Journal Synergies Pays Scandinaves (2014)

[14] Tarigan, H, G.: MenulisSebagaiSuatuKeterampilanBerbahasa (2008)

[15] Tanriverdieva, Khatira.: La Notion de grammairedansl'enseignement/apprentissage du français langue étrangère (2001)

[16] Tsits, Mania.: Le français de l'artculinaireunprojetdictionnairique (2004) 